\title{
Introduction to the Symposium
}

\author{
James F. Hancock \\ Department of Horticulture, Michigan State University, East Lansing, MI 48824
}

There has been increasing concern globally about who will train plant breeders in the future. To date, much of the training has been provided in North American Universities, but the number of public breeders who produce new cultivars is steadily declining (Guner and Werner, 2003). This situation was dramatically portrayed in a news feature in Nature entitled "A dying breed" (Knight, 2003).

The reason for the decline in plant breeding programs is complex, but revolves around two primary factors. First, as plant breeders retire, they are being replaced by scientists involved in more basic genetic studies. This shift is fueled by the perception that private-sector breeding efforts are adequate to meet cultivar needs. Second, cuts in university resources have led to reduced support of field programs, and this has pushed the current public plant breeders to shift their activities toward fundamental or basic studies that can be supported by federal grants and private sector.

The loss of plant breeding programs is of great concern to both our domestic plant breeding industry and the international community. A substantial proportion of the plant breeders in developing nations were trained at U.S. universities, and almost all the private North American breeders attended land-grant universities. The bottom line is that we must find a way to keep a critical mass of applied geneticists and plant breeders at public insti- tutions in the U.S. and around the world if we are to maintain our training programs in plant breeding.

To develop strategies to prevent further erosion of institutional plant breeding training capacity, the Plant Breeding and Genetics Programat Michigan State University, East Lansing, hosted a workshop where members of the entire plant breeding community were represented, including private breeding programs, international training centers, and university breeders. The workshop was party supported by grants from the Michigan Agricultural Experiment Station and the Institute of International Agriculture of Michigan State University.

To begin the symposium, five noted authorities shared their thoughts on the status of plant breeding training in the U.S. and the world: 1) World Bank Senior Economist Michael Morris, with "Building Capacity for International Plant Breeding: What Roles for the Public and Private Sectors," 2) University of Nebraska Eugene W. Price Professor Stephen Baenziger, with "Plant Breeding Training in North America," 3) Seminis Vegetable Seeds Senior Director of R \& D Special Projects Fred Bliss, with "Plant Breeding in the Private Sector of North America," 4) International Rice Research Institute Former Principal Plant Breeder Gurdev Khush, with "Plant Breeding Training in the International Sector," and 5) FAO Cereal and Crops Breeding Senior Of- ficer Elcio Guimarães, with "Assessment of National Plant Breeding and Biotechnology Capacity Worldwide."

When the keynote addresses were completed, breakout groups (Table 1) were formed to address three general topics relevant to plant breeding: 1)What kind of training do plant breeders need, and how can we most effectively provide that training? 2) How will we provide improved varieties of minor and subsistence crops in the future? and 3) How can the public and private sectors most effectively partner to train new generations of plant breeders. Each of the breakout groups discussed a series of questions related to their topic (Table 2) and then presented their deliberations to all symposium participants. A written summary of the reports was produced by a group of Michigan State University plant breeding and genetics graduate students in who had served as recorders during the breakout group deliberations (Table 1).

In the final open discussion of the group, there was a strong consensus that the public must be made more aware of the importance of plant breeding. Too few people understand just what plant breeders do and how they affect human well being. It was suggested that a plantbreeding web page needed to be established, which Todd Werner has subsequently done (http://globalplantbreeding.ncsu.edu/).Acommittee chaired by Rebecca Grumet was set up to generate a fact sheet on the impact of plant

Table 1. Participants in the six breakout groups in the Symposium on Plant Breeding and the Public Sector held at Michigan State University.

Topic I. What kind of training do plant breeders need, and how can we most effectively provide that training?

Group 1A

W. Ronnie Coffman, Cornell Univ.

Group 1B

Chrislyn Drake, Michigan State Univ.

Kaori Ando, Michigan State Univ. ${ }^{2}$

Peter Freymark, Pioneer Hi-Bred International

Amy Iezzoni, Michigan State Univ.

David Mackill, International Rice Inst.

Stephen Baenziger, Univ. Nebraska

Craig Beyrouty, Purdue Univ.

Bob Buehler, Monsanto

Petr Kosina, CIMMYT

Vivian Oduro, Agriculture Research Inst., Ghana

Jim Olmstead, Michigan State Univ. ${ }^{2}$

Desiree Hauteau, Univ. Philippines

Callista Ransom, Michigan State Univ. ${ }^{2}$

Todd Wehner, North Carolina State Univ. ${ }^{y}$

Margaret Smith, Cornell University ${ }^{y}$

Topic II. How will we provide improved varieties of minor and subsistence crops in the future?

Group 2A

Pedro Antonio Arraes, EMBRA-LABRAPA/ARS

Michael Collins, Mississippi State. Univ.

Jim Kelly, Michigan State Univ. ${ }^{y}$

Karim Mareida, Michigan State Univ.

Roger McBroon, Syngenta Seeds, Inc.

Edina Moresco, Scientific Advisor, Texas

Clarice Mensah, Michigan Sate Univ. ${ }^{z}$

Group 2B

Suleiman Bughara, Michigan State Univ. Russ Freed, Michigan State University ${ }^{y}$

Paul Gepts, Univ. of California

Mark Hussey, Texas Agr. Expt. Station

Mohammad Ishiyauku, Inst. Agr. Res., Nigeria

Andrew Nickell, Monsanto

Cholani Weebadde, Michigan State Univ. ${ }^{2}$

Topic III. How can the public and private sector most effectively partner to train plant breeders?

Group 3A

Fred Bliss, Seminis Seeds

Mike Hall, Monsanto

Dave Douches, Michigan State Univ.

Nancy Jo Ehlke, Univ. Minnesota

Elcio Guimareas, FAO, Rome

Ann Marie Thro, USDA-CSREES ${ }^{y}$

Karolyn Terpstra, Michigan State Univ. ${ }^{z}$
Group 3B

Michael Gale, John Innes Foundation Centre, U.K. Gurdev Khush, IRRI

Dechun Wang, Michigan State Univ. Michael Morris, World Bank

Hesham Oraby, Michigan State Univ. ${ }^{z}$ Greg Tolla, Seminis Vegetable Seeds ${ }^{y}$

Veronica Vallejo, Michigan State Univ. Rebecca Grumet, Michigan State Univ. 
Table 2. Topics discussed by the three breakout groups in the Symposium on Plant Breeding and the Public Sector held at Michigan State University.

I. What kind of training do plant breeders need, and how can we most effectively provide that training?

A. What are the educational and training needs of the profession?

1. Is the quantity of graduating students sufficient? Are graduating plant breeding students able to find jobs?

2. What is expected of a plant breeder? How have these expectations changed over the years?

3. How do the goals and needs differ among industry, universities and public institutions (e.g., government and international centers)?

B. What types of training is appropriate?

1. What is the appropriate balance between conventional breeding and newer molecular and genomic technologies?

2. Is there a need for other types of training (e.g., a professional master's degree program, nondegree training programs)?

C. How do we best provide training for future plant breeders?

1. What role should different Universities play in plant breeding training?

2. Where should funding for plant breeding training come from (industry, students, federal funds, land grant system?).

II. How will we provide improved varieties of minor and subsistence crops in the future?

A. What are the challenges to breeding minor and/or subsistence crops?

1. What is the biggest challenge(s) in the breeding of minor and subsistence crops?

2. Which minor/subsistence crops will be most severely affected by lack of plant breeders to work on them?

B. Who should be responsible for the breeding of minor and/or subsistence crops?

1. Is it the role of the public institutions, private companies or international centers for the development of improved varieties of minor crops and new crops? Are there opportunities for partnerships among institutions?

2. What are potential ways to fund minor/subsistence crop breeding programs at Universities and elsewhere?

III. How can the public and private sector most effectively partner to train plant breeders?

A. What are the challenges facing public/private collaborations?

1. What kind of training does the private sector want from Universities, public institutions and international centers?

2. What type of continuing education is appropriate for active private sector breeders and how/who can provide?

B. In what novel ways can the public and private sector work together to train plant breeders?

1. What types of agreements can be made between the public and private sector programs that would be mutually beneficial?

3. How should these partnerships be funded?

breeders and provide it to the Plant Breeding, Genetics, and Genomics, Plant and Animal Systems of USDA-CREES. Russ Freed agreed to explore the formation of an association of plant breeders to bring unity and provide plant breeders with a common voice. A committee lead by Karim Maredia was also organized to develop a strategy to increase collaboration among plant breeders on a global scale. These actions will hopefully put the training of plant breeders at the forefront of international decision and save this dying breed.

\section{Literature Cited}

Guner, N. and T.C. Wehner. 2003. Survey of U.S. land-grant universities for training of plant breeding students. Crop. Sci. 43:1938-1944.

Knight, J. 2003. Crop improvement: A dying breed. Nature 421:568-570. 